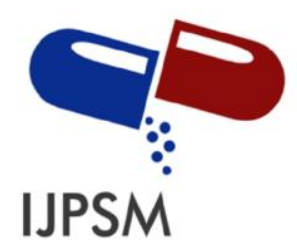

Devi Puspita et al, Int. Journal of Pharmaceutical Sciences and Medicine (IJPSM),

Vol.6 Issue. 2, February- 2021, pg. 1-11

ISSN: 2519-9889

Impact Factor: 3.426

\title{
Overview of Determination of Doxazosin Levels in Pharmaceutical Preparations and Biological Matrix
}

\author{
Devi Puspita $^{1}$; Boy Chandra ${ }^{1}$; Harrizul Rivai ${ }^{2 *}$ \\ ${ }^{1}$ College of Pharmacy (STIFARM), Jl. Raya Siteba Kurao Pagang, Padang 25147, Indonesia \\ ${ }^{2}$ Faculty of Pharmacy, Andalas University, Limau Manih Campus, Padang 25163, Indonesia \\ "Email: harrizul@yahoo.co.id and harrizul@ phar.unand.ac.id \\ DOI: 10.47760/ijpsm.2021.v06i02.001
}

\begin{abstract}
Doxazosin is an alpha-adrenergic antagonist that selectively inhibits the alpha-1 subtype commonly used to treat hypertension and benign prostatic hyperplasia. Determination of doxazosin levels in pharmaceutical preparations and biological matrices needs to be known more deeply. This review gathered information on analytical methods for the determination of doxazosin in pharmaceutical preparations and biological matrices. Information gathering was conducted with Google Scholar from 2000-2020. The results showed that the analysis method of doxazosin could be classified into spectrophotometric methods and chromatographic methods. These two groups of methods are described in more detail in this article. This article is useful for researchers and scientists involved in developing new analytical methods or formulations for doxazosin.
\end{abstract}

Keywords: Doxazosin, Analysis, Spectrophotometry, Chromatography

\section{Introduction}

Doxazosin is a quinazoline derivative with antihypertensive and antineoplastic properties. Doxazosin is an alpha-adrenergic antagonist that selectively blocks alpha-1 adrenergic receptors. Inhibition of alpha-1 adrenergic action on vascular smooth muscle leads to decreased vascular resistance and antihypertensive activity. This agent also shows a high affinity for the alpha-1c adrenoceptor, the primary functional type in the prostate, which can be partly attributed to its effect in treating benign prostatic hyperplasia. Furthermore, doxazosin induces apoptosis in prostate cancer cells, mediated by inhibition of the protein kinase B (PKB)/Akt signaling death receptor regulatory pathway [1]. The chemical structure of doxazosin can be seen in Figure 1 [42].<smiles>COc1cc2nc(N3CCN(C(=O)C4COc5ccccc5O4)CC3)nc(N)c2cc1OC</smiles>

Figure 1: Chemical structure of doxazosin [42] 


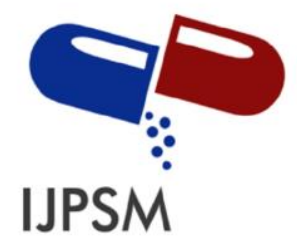

\section{Devi Puspita et al, Int. Journal of Pharmaceutical Sciences and Medicine (IJPSM), Vol.6 Issue. 2, February- 2021, pg. 1-11}

ISSN: 2519-9889

Impact Factor: 3.426

Doxazosin is given orally as doxazosin mesylate, but the dosage is usually expressed on a basis. $1.2 \mathrm{mg}$ of doxazosin mesylate is equivalent to about $1 \mathrm{mg}$ of doxazosin. After an oral dose, the maximum blood pressure drop can occur within 2 to 6 hours, and the effect is maintained for 24 hours, allowing once-daily dosing. Because of the risk of collapse in some patients after the first dose, the initial amount is $1 \mathrm{mg}$, preferably at bedtime. We can increase the quantity after 1 or 2 weeks according to the response. The usual maintenance dose for hypertension is up to $4 \mathrm{mg}$ daily; the amount of $16 \mathrm{mg}$ daily should not be skipped. For benign prostatic hyperplasia, the usual maintenance dose is 2 to $4 \mathrm{mg}$ daily; a quantity of $8 \mathrm{mg}$ daily should not be ignored [2].

Many methods exist in the literature for the determination of doxazosin in various pharmaceutical preparations and biological matrices. These methods can be classified as spectrophotometric methods and chromatographic methods. The following will discuss strategies for determining doxazosin levels in pharmaceutical preparations and biological matrices.

\section{Data Collection}

In compiling this review article, the technique used to collect data is to use literature studies by finding sources or literature in primary data or the form of international journals in the last 20 years (2000-2020). In making this review article, the search for data used online media with doxazosin, assay, pharmaceutical preparations, and biological matrices. Search for the primary references used in this review article through trusted websites such as Mendeley, Science Direct, NCBI, ResearchGate, Google Scholar, and other published and reliable journals.

\section{Spectrophotometric Methods}

The spectrophotometric method is one of the oldest forms of chemical analysis. Spectrophotometry is a measurement technique that has developed rapidly due to technological advances, new materials, and data processing methods. Identification with spectrophotometric process and determination of compound content is based on the existence of a relationship between the position and the absorption intensity of the electromagnetic radiation band, on the one hand, and the molecular structure on the other [3].

In data collection, we found eight different spectrophotometric methods for the determination of doxazosin. Two fluorimetric ways are also available $[4,5]$. As an analytical tool, Spectrofluorimetry provides a clear identity of the compounds present in the sample based on their unique fluorescent properties. These compounds can be analyzed up to the nanogram level [6]. The fluorimetric method developed by Ayat et al. [4] confirms this theory and is the most sensitive method on this list. The acid dye method can provide a more sensitive technique for certain amines and quaternary ammonium compounds that absorb weakly in the ultraviolet region [7]. There are eight different methods based on the acid dye method [8,9].

Atomic spectrum differentiation has considerable advantages for spectrophotometry in the ultraviolet and visible regions. Atomic spectrum differentiation is the key to the potential increase in the resolution of the overlapping bands. It facilitates the detection of poorly absorbed peaks arising from mixing or impurities in the solution. For structural reasons, it allows the precise determination of the maximum wavelength of a particular analyte species and increases the spectrophotometric procedure's sensitivity [10]. Only one first-derived spectrophotometric method for the determination of doxazosin was found [11], and three simple spectrophotometric techniques were found for the determination of doxazosin [12,13, 14]. A summary of all spectrophotometric methods is presented in Table 1 (Appendix).

\section{Chromatographic Methods}

High-performance liquid chromatography (HPLC) was introduced to the pharmaceutical analysis not long after its discovery in the late 1960s. It has now developed into generally applicable analytical methods providing fast and versatile separation possibilities that meet the increasing requirements for purity testing of bulk drugs and pharmaceutical products [15]. Seven different HPLC determinations in the use of U.V. detectors [15-21] were found in the available literature, two of which were based on gradient elution $[16,17]$. 


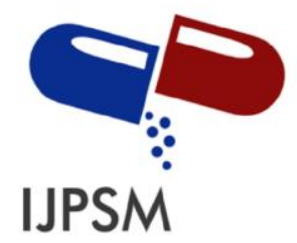

\section{Devi Puspita et al, Int. Journal of Pharmaceutical Sciences and Medicine (IJPSM), Vol.6 Issue. 2, February- 2021, pg. 1-11}

ISSN: 2519-9889

Impact Factor: 3.426

Detectors that measure light absorption in the ultraviolet (U.V.) or visible (VIS) region are used for at least $75 \%$ of applications during the first decade of high-performance liquid chromatography [22]. The UV-Vis absorbance detector monitors the absorption of U.V. or visible light in the HPLC eluent. They are the most common detectors because most of the analytes of interest have U.V. absorbance [23]. These detectors' main disadvantage is that they are fixed wavelength or variable wavelength detectors, and they do not detect aliphatic components in clinically attractive samples [24]. Gradient elution provides a shorter overall analysis with a similar resolution of the critical pair than isocratic elution without sacrificing repeatability in retention time, peak area, and peak height or the linearity of the calibration curve [25]. In this review, two gradient elution methods $[16,17]$ are also included.

Fluorescence detectors with variable excitation and emission wavelengths provide high sensitivity and specificity for detecting and measuring fluorescence compounds but are more useful for quantification than identification [26]. There are some disadvantages reported, such as decreased fluorescence yield by quenching and reabsorption of re-emitted light. The fluorescence intensity can also be affected by the column temperature in gradient chromatography because the chromatographic efficiency is very dependent on the composition of the solvent. Despite all these shortcomings, fluorescence detection is still one of the most valuable techniques for trace analysis by HPLC [27]. During the preparation of this review, six different HPLC methods with fluorescence detection were discovered [28-33].

Hydrophilic interaction liquid chromatography (HILIC), although not a new technique, has recently enjoyed a revival with the introduction of a robust and reproducible stationary phase [34]. HILIC can provide better chromatographic retention for highly polar or ionizable analytes, separate analytes of very different polarity in a reasonable time, increase sensitivity with LC-MS electric spray, and complete analytes and their counterions in the analysis same [35]. The HILIC - MS / MS method for calculating doxazosin was developed and validated by $\mathrm{Ji}$ et al. [36]. This method is claimed to be free of matrix effects as assessed by spiking the analytes after extraction. The combination of chromatography and mass spectrometry is a subject that has attracted a great deal of attention for forty years or so. But the mass spectrometer's complexity means that the majority of chromatography does not have direct access to instrumentation and has to rely on service providers. Therefore they cannot react quickly to the results of the analysis, and as a result, the detectors are very inconvenient to use. However, the combination of HPLC with mass spectrometry allows more definite identification and quantitative determination of compounds that are not entirely resolved by chromatography [37].

Two LC-MS methods [38-39] were also found for the determination of doxazosin. Both approaches have considerable sensitivity and can be used in biological matrices. UPLC has been gradually adopted in industrial laboratories, especially the pharmaceutical industry, due to its high resolution, high speed, and solvent savings since its introduction in early 2004. The UPLC method using sub- $2 \mu \mathrm{m}$ columns can reduce analysis time by up to $80 \%$ compared to HPLC methods using conventional $3.5 \mu \mathrm{m}$ column without sacrificing separation performance. Moreover, the much shorter timeframe significantly reduces the development time of the UPLC method [40]. In this review, only one such practice [41] was found.

A summary of all chromatographic methods is presented in Table 2. The HPLC-UV method [19] is the most sensitive method developed using a U.V. detector. With a LOD (Limit of Detection) of $0.1 \mathrm{ng} / \mathrm{mL}$ [28], this method is the most sensitive in the fluorescence detector category. Despite the many advantages of LC-MS / MS equipment, the methods available in the literature do not appear to produce significant gains in insensitivity. The entire HPLC method developed using a fluorescence detector has good sensitivity. The UPLC-MS / MS method [41] is the most sensitive method among all the techniques developed to determine doxazosin in different matrices. The advantages of such a technique have already been discussed in the text above. A summary of all chromatographic methods is presented in Table 2 (see appendix).

\section{Conclusion}

It is essential to ensure that these analytical methods serve their purpose. This article includes a discussion of method sensitivity and focuses on the advantages or disadvantages of different procedures. In this way, all the analytical methods for determining doxazosin in various pharmaceutical preparations and biological matrices 


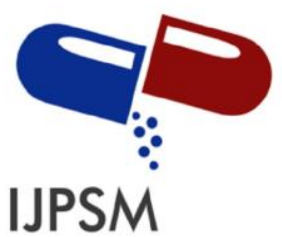

\section{Devi Puspita et al, Int. Journal of Pharmaceutical Sciences and Medicine (IJPSM), Vol.6 Issue. 2, February- 2021, pg. 1-11}

are discussed here. A summary of all spectrophotometric techniques is presented in Table 1, whereas all chromatographic methods are shown in Table 2. This article is useful for researchers and scientists involved in developing new analytical methods or formulations for doxazosin.

\section{References}

[1]. https://pubchem.ncbi.nlm.nih.gov/compound/Doxazosin

[2]. Sweetman SC. Martindale The Complete Drug Reference, $36^{\text {th }}$ Edition. New York: Pharmaceutical Press; 2009.

[3]. Marczenko Z, Balcerzak M. Separation, Preconcentration and Spectrophotometry in Inorganic Analysis. Netherlands: Elsevier Science Publishers; 2000.

[4]. Ayad MM, Abdellatef HE, Hosny MM, Sharaf YA. Spectrophotometric And Spectrofluorimetric Determination of Amlodipine Besylate and Doxazosin Mesylate In Bulk and In Dosage Forms via Hantzsch Reaction. Int J Pharm And Biomed Res. 2012; 3(2):111-116.

[5]. Ammar RA, El-Brashy AM, Al-Sahly TN. Spectrophotometric and Spectrofluorometric Determination of Doxazosin Mesylate in Tablets via Eosin Y. Asian J of Chem. 2014; 26(1): 57-62.

[6]. Nahata A. Spectrofluorimetry as an Analytical Tool. Pharm Anal Acta. 2011; 2(8): 1-2.

[7]. Shrivastava A, Saxena P, \& Gupta VB, Spectrophotometric Estimation of Tamsulosin Hydrochloride by Acid-Dye Method. Pharm Methods. 2011; 2(1): 53-60.

[8]. Aydodmup, Z., \& Barla, A. Spectrophotometric Determination of Doxazosin Mesylate in Tablets by Ion-Pair and Charge-Transfer Complexation Reactions. J of AOAC Int. 2009; 92(1): 131-137

[9]. el-sheik R, Esmail NS, Gouda A.A., Basset WA. Extractive Spectrophotometric Determination of Some $\alpha-$ Adrenergic-Antagonists in Pure Forms and In Pharmaceutical Formulations. Chem Industry \& Chem Enginee Quart. 2012; 18(1) 179-191.

[10]. Sommer L. Analytical Absorption Spectrophotometry in The Visible and Ultraviolet, The Principles. Netherlands: Elsevier Science Publishers; 1989.

[11]. Bebawy LI, Moustafa AA, Abo-Talib, NF. Stability-Indicating Methods for The Determination of Doxazosin Mesylate and Celecoxib. J of Pharm and Biomed Anal. 2002; 27:779-793.

[12]. Altiokka G. Voltammetric Determination of Doxazosin in Tablets Using Rotating Platinum Electrode. J of Pharm and Biomed Anal. 2001; 25:387-391.

[13]. Chaudhari SP, Ratmaparkhi MP, Kotian NR, Bhadgale MM, \& Bafna VC. Development and Validation of U.V. Spectrophotometric Method for Determination of Doxazosin Mesylate in Tablet Formulation. Der Pharm Sinica. 2012, 3(4): 427-432.

[14]. Naidu NVS, Naidu KB, Suguna P. Development and Validation of U.V.-Spectrophotometric Method for The Determination of Doxazosin Mesylate in Pharmaceutical Formulations. Anal Chem An Indian J. 2013; 12(1): 7-14.

[15]. Sreevatsav SK. Sunder SK, Maleraju J, Racha H. Analytical Method Development and Validation of Doxazosin Mesylate Uncoated Tablets by R.P.-HPLC. Int J of Biomed Res. 2013; 4(9): 465- 476

[16]. European Pharmacopoeia, 5th Edition. Europe: secretariat of the European Pharmacopoeia for the quality of medicine; 2005.

[17]. Shrivastava A, \& Gupta VB. Stability-Indicating R.P.-HPLC Method for The Simultaneous Determination of Prazosin, Terazosin, and Doxazosin in Pharmaceutical Formulations. Scie Pharm. 2012; 80: 619-631.

[18]. Japanese Pharmacopoeia Committee. The Japanese 56 Pharmacopoeia $16^{\text {th }}$ Ed. Tokyo: The Ministry of Health, Labour and Welfare. 2016.

[19]. Dhanya B, Suganthi A, Sen AK, Sahoo U, Seth AK. Determination of Doxazosin Mesylate in Tablets by RP-HPLC. Indian J of Pharm Scie. 2011; 73(1): 115-120.

[20]. Naidu NVS, Reddy MRM, Suguna P. Development and Validation of The HPLC Method for The Analysis of Doxazosin in Bulk Drug and Pharmaceutical Dosage Forms. Int J of Pharm Scie and Res. 2012; 3(8): 2705-2711.

[21]. Rao KS, Deb KB, Rao MEB, Patro S.S., Patnaik AK. Development and Validation of Stability Indicating Analytical Method for Doxazosin Mesylate and its Application to Kinetic Studies. Chem Scie J. 2012: 1-10.

[22]. Vickrey TM. 1983. Liquid Chromatography Detectors Volume 23. Newyork: Marcel Dekkar Inc; 1983.

[23]. Papadoyannis IN. HPLC in Clinical Chemistry. Newyork: Marcel Dekker; 1990.

[24]. Dong, MW. Modern HPLC for Practicing Scientists. New Jersey: John Wiley and Sons, Inc Publications; 2006.

[25]. Karch SB. Postmortem Toxicology of Abused Drugs. USA: CRC Press; 2008.

[26]. Schellinger AP, Carr PW. Isocratic and Gradient Elution Chromatography: A Comparison in Terms of Speed, Retention Reproducibility and Quantitation, J of Chromato A. 2006; 1109(2): 253-266.

[27]. Swadesh J.K. HPLC: Practical and Industrial Applications, $2^{\text {nd }}$ Edition. USA: CRC Press; 2001. 


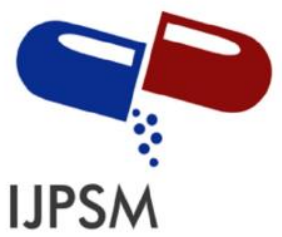

\section{Devi Puspita et al, Int. Journal of Pharmaceutical Sciences and Medicine (IJPSM), Vol.6 Issue. 2, February- 2021, pg. 1-11}

ISSN: 2519-9889

Impact Factor: 3.426

[28]. Bhavesh D, Pinal S, Saroj V, Shivprakash. Determination of Doxazosin in Human Plasma by Reversed-Phase Ion Pair High-Performance Liquid Chromatography with Fluorescence Detection. Indian J of Pharm Scie. 2002; 64(4): 354-356.

[29]. Sripalakit P, Nermhom P, Saraphanchotiwitthaya A. Improvement of Doxazosin Determination in Human Plasma Using High-Performance Liquid Chromatography with Fluorescence. Detec J of Chromato Scie. 2005; 43: 63-66.

[30]. Sripalakit P, Nermhom P, Saraphanchotiwitthaya A. Validation and Pharmacokinetic Application of A Method for Determination of Doxazosin in Human Plasma by High-Performance Liquid Chromatography. Biomed Chromato. 2006; 20(8): 729-735.

[31]. Kaewvichit S, Thongsawat S, Taesotikul W, Wongsinsup C, Yotsawimonwat S, Duangrat C, Niwatananum K. Bioequivalence Study of Doxazosin Tablets in Healthy Thai Male Volunteers. Thai J of Pharm 2007; 29(2): 19-24.

[32]. Kwon YH, Gwak HS, Yoon SJ, Chun IK. Pharmacokinetics of Doxazosin Gastrointestinal Therapeutic System after Multiple Administration in Korean Healthy Volunteers. Drug Develop and Industrial Pharm. 2007; 33(8): 824-829.

[33]. Wongsinsup C, Taesotikul W, Kaewvichit S, Sangsrijan S, Sangsrijan S. Simple Method of Extraction and Determination of Doxazosin Mesylate in Human Plasma by High-Performance Liquid Chromatography with Fluorescence Detector. CMU. J of Natur Scie. 2007; 6(2): 231-240.

[34]. Cubbon S, Antonio C, Wilson J, Thomas-Oates J. Metabolomic Applications of HILIC-LC-MS. Mass Spectro Reviews. 29(5), (2010) 671-684.

[35]. Zhang W, Han F, Zhao H, Lin ZJ, Huang QM, Weng N. Determination of Metformin in Rat Plasma by HILICMS/MS Combined with Tecan Automation and Direct Injection. Biomed Chromato. 2011; 26(10): 1163-1169.

[36]. Ji HY, Park EJ, Lee KC, \& Lee HS. Quantification of Doxazosin in Human Plasma Using Hydrophilic Interaction Liquid Chromatography with Tandem Mass Spectrometry. J of Separa Scie. 2008; 31(9): 1628-1633.

[37]. Ardrey RE. Liquid Chromatography-Mass Spectrometry: An Introduction. England: John Wiley and Sons; (2003)

[38]. Chytil L, Strauch B, Cvačka J, Marešová V, Jr. JW, Holaj R, Planar O. Determination of Doxazosin and Verapamil in Human Serum by Fast LC-MS/MS: Application to Document Non-Compliance of Patients. J of Chromato B. 2010; 878: 3167-3173.

[39]. Erceg M, Cindric M, Frketic LP, Vertzoni M, Cetina-Cižmek B, Reppas CA. L.C.-MS-MS Method for Determination of Low Doxazosin Concentrations in Plasma After Oral Administration to Dogs. J of Chromato Scie. 2010; 48: 114-119.

[40]. Chen S, Kord A. UPLC Method Development In Ultra-High-Performance Liquid Chromatography and its Applications First Edition, editor: Q. Alan Xu. John Wiley \& Sons, Inc; 2013.

[41]. Al-Dirbashi OY, Aboul-Enein HY, Jacob M, Al-Qahtani K, Rashed MS. UPLC-MS/MS Determination of Doxazosine in Human Plasma. Anal and Bioanal Chem. 2006; 38: 1439-1443.

[42]. Indonesia. Kementerian Kesehatan RI. Direktorat Jenderal Kefarmasian dan Alat Kesehatan. Farmakope Indonesia Edisi VI. Jakarta: Kementerian Kesehatan RI. 2020

\section{A Brief Author Biography}

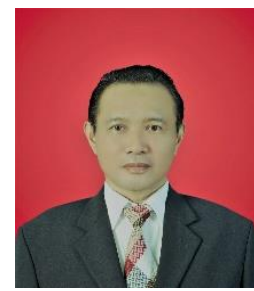

Prof. Dr. Harrizul Rivai, M.S., was born in Payakumbuh, West Sumatra, on 4 September 1953. His father is Rivai Said, and his mother is Saridahanum Syofyan. The Author obtained a Bachelor of Pharmacy from the Department of Pharmacy, Faculty of Mathematics and Natural Sciences, Padjajaran University, Bandung (1976), a Master of Science degree from the Bandung Institute of Technology (1984), and a Doctorate from the Department of Chemistry, Faculty of Mathematics and Natural Sciences, Andalas University, Padang (2011). Now the Author is a Professor and Researcher at the Faculty of Pharmacy, Andalas University, Padang. The Author also serves as Deputy Chair of Academic Affairs at the YPTIK Padang College of Pharmacy (STIFARM). The Author wrote the book "Principles of Chemical Examination" (Publisher UI-Press, 1995), translated the book "Pharmaceutical Statistics" (EGC Medical Book Publishers, 2010), and wrote "Chapter 4" in the book "Recent Research Advances in Biology Vol. 4 "(International Book Publisher, India, and United Kingdom, 2020). The Author has also written articles in various international journals in various science fields, such as chemistry, biology, and pharmacy. 


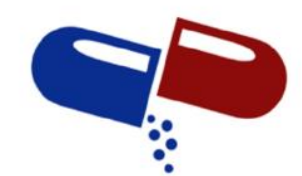

\section{IJPSM}

Devi Puspita et al, Int. Journal of Pharmaceutical Sciences and Medicine (IJPSM),

Vol.6 Issue. 2, February- 2021, pg. 1-11

ISSN: 2519-9889

Impact Factor: 3.426

Appendix

Table 1: Spectrophotometric methods for the determination of doxazosin levels

\begin{tabular}{|c|c|c|c|c|c|c|c|}
\hline No. & Principles & Wavelength & Linear Range & $\begin{array}{l}\text { Detection } \\
\text { Limit }\end{array}$ & $\begin{array}{l}\text { Quantitation } \\
\text { Limits }\end{array}$ & Application & Ref. \\
\hline 1. & $\begin{array}{l}\text { Simple spectrophotometric test by } \\
\text { dissolving drugs in water }\end{array}$ & $330 \mathrm{~nm}$ & $\begin{array}{c}1.0 \times 10^{-5} \mathrm{M} \\
\text { and } \\
5.0 \times 10^{-5} \mathrm{M}\end{array}$ & - & $1.0 \times 10^{-5} \mathrm{M}$ & Raw material & {$[12]$} \\
\hline 2. & $\begin{array}{l}\text { Shows the spectrophotometric stability of } \\
\text { the first derivative }\end{array}$ & $256 \mathrm{~nm}$ & $8-120 \mu \mathrm{g} / \mathrm{mL}$ & - & $0.8 \mathrm{~g} / \mathrm{mL}$ & Bulk and Tablets & {$[11]$} \\
\hline \multirow[t]{4}{*}{3.} & \multirow{2}{*}{$\begin{array}{l}\text { Ion pair complexes with sulfophthalein } \\
\text { acid bromocresol purple dye (BCP) and } \\
\text { bromophenol blue (BPB) in phosphate } \\
\text { buffer } \mathrm{pH} 3,3 \text { and } 4,5\end{array}$} & $\begin{array}{l}\text { BCP: } \\
403 \mathrm{~nm}\end{array}$ & $\begin{array}{c}\text { BCP: } \\
3-18 \mu \mathrm{g} / \mathrm{mL}\end{array}$ & $\begin{array}{l}\mathrm{BCP}: \\
0,314 \\
\mu \mathrm{g} / \mathrm{mL}\end{array}$ & $\begin{array}{r}\text { BCP: } \\
1,045 \\
\mu \mathrm{g} / \mathrm{mL} \\
\end{array}$ & \multirow[t]{4}{*}{ Tablet } & \multirow[t]{4}{*}[8]{} \\
\hline & & $\begin{array}{l}\text { BPB: } \\
411 \mathrm{~nm}\end{array}$ & $\begin{array}{c}\text { BPB: } \\
3-20 \mu \mathrm{g} / \mathrm{mL}\end{array}$ & $\begin{array}{l}\text { BPB: } \\
0,408 \\
\mu \mathrm{g} / \mathrm{mL}\end{array}$ & $\begin{array}{c}\text { BPB: } \\
1,360 \mu \mathrm{g} / \mathrm{mL}\end{array}$ & & \\
\hline & \multirow{2}{*}{$\begin{array}{l}\text { Charge transfer reaction of the drug as an } \\
\text { n-electron donor with either 2,3-dichloro- } \\
5,6 \text {-dicyano-1,4-benzoquinone (DDQ) } \\
\text { or 7,7,8,8-tetracyanoquinodimethane } \\
\text { (TCNQ) as pi-acceptors, to give colored } \\
\text { radical anions }\end{array}$} & $\begin{array}{c}\text { Q: } \\
457 \mathrm{~nm}\end{array}$ & $\begin{array}{c}\text { Q: } \\
15-95 \mu \mathrm{g} / \mathrm{mL}\end{array}$ & $\begin{array}{l}\mathrm{Q}: \\
1,935 \\
\mu \mathrm{g} / \mathrm{mL}\end{array}$ & $\begin{array}{c}\text { Q: } \\
6,449 \mu \mathrm{g} / \mathrm{mL}\end{array}$ & & \\
\hline & & $\begin{array}{l}\text { TCNQ: } \\
838 \mathrm{~nm}\end{array}$ & $\begin{array}{l}\text { TCNQ: } \\
10-100 \\
\mu \mathrm{g} / \mathrm{mL}\end{array}$ & $\begin{array}{l}\text { TCNQ: } \\
1,610 \\
\mu \mathrm{g} / \mathrm{mL}\end{array}$ & $\begin{array}{c}\text { TCNQ: } \\
5,367 \mu \mathrm{g} / \mathrm{mL}\end{array}$ & & \\
\hline \multirow[t]{2}{*}{4.} & \multirow{2}{*}{$\begin{array}{l}\text { Acetylacetone with formaldehyde reacts } \\
\text { with primary amines by the Hantzsch } \\
\text { reaction to form a yellow product } \\
\text { (dihydrolutidine derivatives) measured } \\
\text { spectrophotometry and Spectrofluorimetry }\end{array}$} & $336 \mathrm{~nm}$, & $8-36 \mu \mathrm{g} / \mathrm{mL}$ & $\begin{array}{c}0,693 \\
\mu \mathrm{g} / \mathrm{mL}\end{array}$ & $2,289 \mu \mathrm{g} / \mathrm{mL}$ & \multirow[t]{2}{*}{$\begin{array}{l}\text { Pure Doxazosin and } \\
\text { Tablets }\end{array}$} & \multirow[t]{2}{*}[4]{} \\
\hline & & $\begin{array}{c}\lambda_{\mathrm{ex}}: \\
400 \mathrm{~nm}\end{array}$ & $0,02-0,22$ & $\begin{array}{l}0,01 \\
\mu \mathrm{g} / \mathrm{mL}\end{array}$ & $0,02 \mu \mathrm{g} / \mathrm{mL}$ & & \\
\hline
\end{tabular}




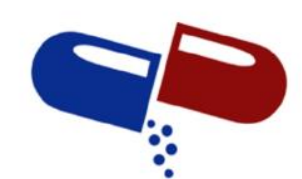

\section{IJPSM}

Devi Puspita et al, Int. Journal of Pharmaceutical Sciences and Medicine (IJPSM),

Vol.6 Issue. 2, February- 2021, pg. 1-11

ISSN: 2519-9889

Impact Factor: 3.426

\begin{tabular}{|c|c|c|c|c|c|c|c|}
\hline & & $\begin{array}{c}\lambda_{\mathrm{em}}: \\
475 \mathrm{~nm}\end{array}$ & $\mu \mathrm{g} / \mathrm{mL}$ & & & & \\
\hline 5. & $\begin{array}{l}\text { U.V. spectrophotometric test of drug } \\
\text { solution in } 0.01 \mathrm{~N} \mathrm{HCl} \text { solvent }\end{array}$ & $245 \mathrm{~nm}$ & $2-10 \mu \mathrm{g} / \mathrm{mL}$ & & & Tablet & [13] \\
\hline \multirow[t]{4}{*}{6.} & \multirow{4}{*}{$\begin{array}{l}\text { Ion pair complexes with bromocresol } \\
\text { green, bromothymol blue, methyl orange, } \\
\text { and alizarin red dyes in acid buffer pH 3.0- } \\
5.0 \text {. }\end{array}$} & $418 \mathrm{~nm}$ & $\begin{array}{c}1,0-12 \\
\mu \mathrm{g} / \mathrm{mL}^{-1}\end{array}$ & $\begin{array}{c}0,275 \\
\mu \mathrm{g} / \mathrm{mL}^{-1}\end{array}$ & $0,915 \mu \mathrm{g} / \mathrm{mL}^{-1}$ & & \\
\hline & & $414 \mathrm{~nm}$ & $\begin{array}{c}1,0-16 \\
\mu \mathrm{g} / \mathrm{mL}^{-1}\end{array}$ & $\begin{array}{c}0,296 \\
\mu \mathrm{g} / \mathrm{mL}^{-1}\end{array}$ & $0,988 \mu \mathrm{g} / \mathrm{mL}^{-1}$ & & \\
\hline & & $425 \mathrm{~nm}$ & $\begin{array}{c}1,0-12 \\
\mu \mathrm{g} / \mathrm{mL}^{-1}\end{array}$ & $\begin{array}{c}0,164 \\
\mu \mathrm{g} / \mathrm{mL}^{-1}\end{array}$ & $0,547 \mu \mathrm{g} / \mathrm{mL}^{-1}$ & & \\
\hline & & $426 \mathrm{~nm}$ & $\begin{array}{c}4,0-50 \\
\mu \mathrm{g} / \mathrm{mL}^{-1}\end{array}$ & $\begin{array}{c}0,672 \\
\mu \mathrm{g} / \mathrm{mL}^{-1}\end{array}$ & $\begin{array}{c}2,24 \\
\mu \mathrm{g} / \mathrm{mL}^{-1}\end{array}$ & & \\
\hline 7. & $\begin{array}{l}\text { A simple spectrophotometric test based on } \\
\text { the formation of a complex reaction with } \\
1,10-\text { Phenanthrroline } / \mathrm{FeCl}_{3}\end{array}$ & $510 \mathrm{~nm}$ & $10-60 \mu \mathrm{g} / \mathrm{mL}$ & $\begin{array}{c}0,60916 \\
\mu \mathrm{g} / \mathrm{mL}\end{array}$ & $\begin{array}{r}1,845 \\
\mu \mathrm{g} / \mathrm{mL}\end{array}$ & Tablet & [14] \\
\hline \multirow[t]{2}{*}{8.} & \multirow{2}{*}{$\begin{array}{l}\text { Ion pair complexes with Eosin Y reagent } \\
\text { in acetate buffer at } \mathrm{pH} 3 \text { were measured } \\
\text { spectrophotometrically and } \\
\text { Spectrofluorimetry. }\end{array}$} & $547 \mathrm{~nm}$ & $\begin{array}{c}2-14 \\
\mu \mathrm{g} / \mathrm{mL}\end{array}$ & $\begin{array}{r}0,393 \\
\mu \mathrm{g} / \mathrm{mL}\end{array}$ & $1,191 \mu \mathrm{g} / \mathrm{mL}$ & \multirow[t]{2}{*}{ Tablet } & \multirow[t]{2}{*}{ [5] } \\
\hline & & $\begin{array}{c}\lambda \mathrm{ex}: \\
340 \mathrm{~nm} \\
\Lambda \mathrm{em}: \\
570 \mathrm{~nm}\end{array}$ & $1-10 \mu \mathrm{g} / \mathrm{mL}$ & $\begin{array}{l}0,0784 \\
\mu \mathrm{g} / \mathrm{mL}\end{array}$ & $0,241 \mu \mathrm{g} / \mathrm{mL}$ & & \\
\hline
\end{tabular}




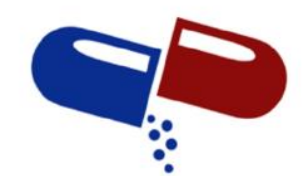

\section{IJPSM}

Devi Puspita et al, Int. Journal of Pharmaceutical Sciences and Medicine (IJPSM),

Vol.6 Issue. 2, February- 2021, pg. 1-11

ISSN: 2519-9889

Impact Factor: 3.426

Table 2: Chromatographic methods for determining doxazosin levels

\begin{tabular}{|c|c|c|c|c|c|c|c|c|c|}
\hline No. & Method & $\begin{array}{l}\text { Chromatographic } \\
\text { conditions }\end{array}$ & Mobile phase & $\begin{array}{l}\text { Linearit } \\
\text { y range }\end{array}$ & Detection & $\begin{array}{l}\text { Detection } \\
\text { limit }\end{array}$ & $\begin{array}{l}\text { Quantitation } \\
\text { limit }\end{array}$ & Application & Ref. \\
\hline 1 & HPLC- U.V. & $\begin{array}{l}\text { Columns with an inner } \\
\text { diameter of } 3.9 \mathrm{~mm} \text { and } \\
\text { a length of } 15 \mathrm{~cm} \text { were } \\
\text { packed with } \\
\text { octadecylsilane for liquid } \\
\text { chromatography ( } 4 \mu \mathrm{m} \\
\text { particle diameter). } \\
\text { Temperature } 25^{\circ} \mathrm{C}\end{array}$ & $\begin{array}{l}\text { A mixture of } 0.05 \mathrm{~mol} / \mathrm{L} \\
\text { Potassium Dihydrogen } \\
\text { Phosphate T.S. pH 3.0, } \\
\text { Methanol and Acetonitrile (12: } \\
\text { 8: 3) }\end{array}$ & - & $246 \mathrm{~nm}$ & - & - & Pure Doxazosin & [18] \\
\hline 2 & $\begin{array}{l}\text { HPLC-UV } \\
\text { gradient }\end{array}$ & $\begin{array}{l}250 \times 4.0 \mathrm{~mm} \\
\text { octylsilane silica gel } \\
\text { base active column }\end{array}$ & $\begin{array}{l}10 \mathrm{~g} / \mathrm{L} \mathrm{H}_{3} \mathrm{PO}_{4} \text { and } 10 \mathrm{~g} / \mathrm{L} \\
\text { phosphoric acid solution in } \\
\text { ACN. Temperature } 35^{\circ} \mathrm{C}\end{array}$ & - & $210 \mathrm{~nm}$ & - & - & $\begin{array}{l}\text { Test and related } \\
\text { compounds }\end{array}$ & [16] \\
\hline 3 & $\begin{array}{l}\text { RP-HPLC- } \\
\text { UV }\end{array}$ & $\begin{array}{l}\text { RP-C18 Chromolith } \\
\text { Column }\end{array}$ & $\begin{array}{l}\text { The mixture of buffered } \\
\text { potassium phosphate and } \\
\text { methanol }(40: 60 \mathrm{v} / \mathrm{v})\end{array}$ & $\begin{array}{c}1-5 \\
\mu \mathrm{g} / \mathrm{ml}\end{array}$ & $251 \mathrm{~nm}$ & $0,1 \mu \mathrm{g} / \mathrm{mL}$ & $0,5 \mu \mathrm{g} / \mathrm{mL}$ & Tablet & {$[18]$} \\
\hline 4 & HPLC-UV & $\begin{array}{l}\text { RP-C18 Chromolith } \\
\text { Column, Column } 100 \\
\text { mm x } 10 \mu \mathrm{m}\end{array}$ & $\begin{array}{l}\text { The mixture of Methanol and } \\
\text { Potassium Dihydrogen } \\
\text { Orthophosphate with a ratio of } \\
60: 40 \text {. And adjust the } \mathrm{pH} \text { to } 5.0 \\
\pm 0.05 \text { with sodium hydroxide } \\
\text { solution. }\end{array}$ & $\begin{array}{l}50-150 \\
\mu \mathrm{g} / \mathrm{mL}\end{array}$ & $251 \mathrm{~nm}$. & - & - & $\begin{array}{l}\text { Pharmaceutical } \\
\text { preparations }\end{array}$ & [20] \\
\hline 5 & HPLC-UV & $\begin{array}{l}\text { LiChroCART } \\
\text { Lichrosphere } 100, \mathrm{C} 18, \\
\text { R.P. column }(250 \mathrm{~mm} \times \\
4 \mathrm{~mm} \times 5 \mu \mathrm{m}) \\
\text { maintained at ambient }\end{array}$ & Methanol-water (60:40\% v/v) & $\begin{array}{l}1-300 \\
\mu \mathrm{g} / \mathrm{mL}- \\
1\end{array}$ & $247 \mathrm{~nm}$ & $0,3 \mu \mathrm{g} / \mathrm{mL}$ & $1,2 \mu \mathrm{g} / \mathrm{mL}$ & $\begin{array}{l}\text { Pharmaceutical } \\
\text { preparations }\end{array}$ & [21] \\
\hline
\end{tabular}




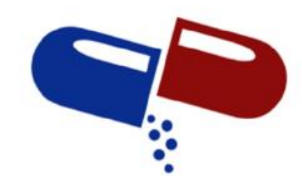

\section{IJPSM}

Devi Puspita et al, Int. Journal of Pharmaceutical Sciences and Medicine (IJPSM),

Vol.6 Issue. 2, February- 2021, pg. 1-11

ISSN: 2519-9889

Impact Factor: 3.426

\begin{tabular}{|c|c|c|c|c|c|c|c|c|c|}
\hline & & $\begin{array}{l}\text { temperature, eluted with } \\
\text { the mobile phase at a } \\
\text { flow rate of } 1 \mathrm{~mL} / \mathrm{min} \\
\text { for } 10 \text { minutes }\end{array}$ & & & & & & & \\
\hline 6. & $\begin{array}{l}\text { HPLC-UV } \\
\text { gradient }\end{array}$ & $\begin{array}{l}\text { Kromasil C18 column } \\
(250 \times 4.6 \mathrm{~mm}, 5.0 \mu \mathrm{m})\end{array}$ & $\begin{array}{l}\text { Ammonium acetate, }(\mathrm{A}: \mathrm{B}: \mathrm{C}) \\
\text { is: } 60: 40: 0: 0 \text { for } 8 \text { minutes, } \\
\text { 60: } 20: 20: 0 \text { for } 1 \text { minute, } 60 \text { : } \\
0: 40: 0 \text { for } 5 \text { minutes, and } \\
\text { 60:40: } 0: 0 \text { gradient for } 1 \\
\text { minute for system equilibrium }\end{array}$ & $\begin{array}{l}2-500 \\
\mu \mathrm{g} / \mathrm{mL}\end{array}$ & $254 \mathrm{~nm}$ & $\begin{array}{l}0,109 \\
\mu \mathrm{g} / \mathrm{mL}\end{array}$ & $0,332 \mu \mathrm{g} / \mathrm{mL}$ & Tablet & [17] \\
\hline 7. & HPLC-UV & $\begin{array}{l}\text { Chromolith RP-C18 } \\
\text { column }[100 \mathrm{~mm} \times 4.6 \\
\mathrm{mm} \times 10 \mu \mathrm{m}]\end{array}$ & $\begin{array}{l}\text { Phosphate Buffer: Methanol } \\
\text { ratio (40:60) }\end{array}$ & $\begin{array}{l}50-150 \\
\mu \mathrm{g} / \mathrm{mL}\end{array}$ & $251 \mathrm{~nm}$ & - & - & Tablet & {$[15]$} \\
\hline 8. & RP-HPLC-F & $\begin{array}{l}\text { Hypersil, } 5 \mu, \text { ODS, C18, } \\
5 \mu \mathrm{m}, 250 \times 4.6 \mathrm{~mm} \\
\text { with guard column A } 30 \\
\times 4.6 \mathrm{~mm}\end{array}$ & $\begin{array}{l}\text { Methanol: Heptane Sulfonic } \\
\text { Acid Buffer }(\mathrm{pH} 3.4,0.02 \mathrm{M}) \\
\text { with a ratio of } 55: 45(\mathrm{v} / \mathrm{v}) \\
\text { Flow rate } 1.2 \mathrm{~mL} / \mathrm{min} \text {. }\end{array}$ & $\begin{array}{l}0,5-30 \\
\mathrm{ng} / \mathrm{mL}\end{array}$ & $\begin{array}{l}\text { Fluorescence } \\
\lambda_{\mathrm{ex}}=246 \mathrm{~nm} \\
\lambda_{\mathrm{em}}=370 \\
\mathrm{~nm}\end{array}$ & $0,1 \mathrm{ng} / \mathrm{mL}$ & $0,5 \mathrm{ng} / \mathrm{mL}$ & Blood plasma & {$[28]$} \\
\hline 9. & HPLC-F & $\begin{array}{l}\text { The Apollo C18 column } \\
(250 \times 4.6 \mathrm{~mm} \text {, id, } 5 \mu \mathrm{m} \text {, } \\
250 \mathrm{~A}) \text { (Alltech, } \\
\text { Deerfield, IL, USA) is } \\
\text { equipped with a } \\
\text { protective cartridge that } \\
\text { can be refilled in the } \\
\text { Apollo C18 package ( } 7.5 \\
\times 4.6 \mathrm{~mm} \text { id, } 5 \mu \mathrm{m})\end{array}$ & $\begin{array}{l}\text { Methanol - Acetonitrile - } \\
0.04 \mathrm{M} \text { Disodium Hydrogen } \\
\text { Orthophosphate }(22: 22: 56 \mathrm{v} / \mathrm{v}) \\
\text { adjusted to pH } 5 \text { with } \\
\text { phosphoric acid } 0.9 \text {. All } \\
\text { separations were performed } \\
\text { isocratically with a flow rate of } \\
1.2 \mathrm{~mL} \text {, and the column } \\
\text { temperature was maintained at } \\
\text { room temperature }\end{array}$ & $\begin{array}{l}0,5-20 \\
\mathrm{ng} / \mathrm{mL}\end{array}$ & $\begin{array}{l}\text { Fluorescence } \\
\lambda_{\text {ex }}=246 \mathrm{~nm} \\
\lambda_{\text {em }}=389 \mathrm{~nm}\end{array}$ & $\begin{array}{l}0,125 \\
\mathrm{ng} / \mathrm{mL}\end{array}$ & $0,5 \mathrm{ng} / \mathrm{mL}$ & $\begin{array}{l}\text { Analysis of } \\
\text { blood plasma } \\
\text { samples }\end{array}$ & [29] \\
\hline
\end{tabular}




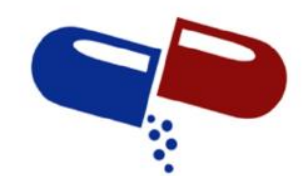

\section{IJPSM}

Devi Puspita et al, Int. Journal of Pharmaceutical Sciences and Medicine (IJPSM),

Vol.6 Issue. 2, February- 2021, pg. 1-11

ISSN: 2519-9889

Impact Factor: 3.426

\begin{tabular}{|c|c|c|c|c|c|c|c|c|c|}
\hline 10. & HPLC-F & $\begin{array}{l}\text { The Apollo C18 column } \\
(250 \times 4.6 \mathrm{~mm} \text {, id, } 5 \mu \mathrm{m} \text {, } \\
250 \mathrm{~A}) \text { (Alltech, } \\
\text { Deerfield, IL, USA) is } \\
\text { equipped with a } \\
\text { protective cartridge that } \\
\text { can be refilled in the } \\
\text { Apollo C18 package }(7.5 \\
\times 4.6 \mathrm{~mm} \text { id, } 5 \mu \mathrm{m}) .\end{array}$ & $\begin{array}{l}\text { Methanol - Acetonitrile - } \\
0.04 \mathrm{M} \text { Disodium Hydrogen } \\
\text { Orthophosphate }(22: 22: 56 \mathrm{v} / \mathrm{v}) \\
\text { adjusted to pH } 5 \text { with } \\
\text { phosphoric acid } 0.9 \text {. All } \\
\text { separations were performed } \\
\text { isocratically with a flow rate of } \\
1.2 \mathrm{~mL} \text {, and the column } \\
\text { temperature was maintained at } \\
\text { room temperature }\end{array}$ & $\begin{array}{l}1-25 \\
\mathrm{ng} / \mathrm{mL}\end{array}$ & $\begin{array}{l}\lambda_{\mathrm{ex}}=246 \mathrm{~nm} \\
\lambda_{\mathrm{em}}=389 \mathrm{~nm}\end{array}$ & $0,5 \mathrm{ng} / \mathrm{mL}$ & $1 \mathrm{ng} / \mathrm{mL}$ & Blood plasma & [30] \\
\hline 11 & HPLC-F & $\begin{array}{l}\text { C18 column }(\text { Hypersil, } \\
250 \times 4 \mathrm{~mm}, 5 \mu \mathrm{m}), \\
\text { column temperature } 25 \\
{ }^{\circ} \mathrm{C}\end{array}$ & $\begin{array}{l}\text { Acetonitrile: } 10 \mathrm{mM} \\
\text { Ammonium Acetate }(40: 60) \\
\text { with a flow rate of } 1.0 \mathrm{~mL} / \mathrm{min} .\end{array}$ & $\begin{array}{l}1-50 \\
\mathrm{ng} / \mathrm{mL}\end{array}$ & $\begin{array}{l}\lambda_{\mathrm{ex}}=246 \mathrm{~nm} \\
\lambda_{\mathrm{em}}=376 \mathrm{~nm}\end{array}$ & - & $1 \mathrm{ng} / \mathrm{mL}$ & $\begin{array}{l}\text { Bioequivalence } \\
\text { studies }\end{array}$ & [31] \\
\hline 12. & HPLC-F & $\begin{array}{l}\text { Column C18 (4.6 x } 250 \\
\mathrm{~mm}, 5 \mu \mathrm{m})\end{array}$ & $\begin{array}{l}\text { Water: Acetonitrile: } \\
\text { Triethylamine (68: } 32: 0.2 \mathrm{v} / \mathrm{v} \text {, } \\
\text { pH 5.0) with a flow rate of } 1.2 \\
\mathrm{~mL} / \mathrm{min} \text {. }\end{array}$ & - & $\begin{array}{l}\lambda_{\mathrm{ex}}=246 \mathrm{~nm} \\
\lambda_{\mathrm{em}}=389 \mathrm{~nm}\end{array}$ & $0,2 \mathrm{ng} / \mathrm{mL}$ & $1 \mathrm{ng} / \mathrm{mL}$ & $\begin{array}{l}\text { Pharmacokinetic } \\
\text { studies }\end{array}$ & [32] \\
\hline 13. & HPLC-F & $\begin{array}{l}\text { Hypersil ODS Column } \\
(5 \mu \mathrm{m}, 125 \text { x } 4.0 \mathrm{~mm})\end{array}$ & $\begin{array}{l}\text { Acetonitrile: } 10 \mathrm{mM} \\
\text { Ammonium Acetate }(40: 60) \\
\text { with a flow rate of } 1.0 \mathrm{~mL} / \mathrm{min}\end{array}$ & $\begin{array}{l}1,0-50 \\
\mathrm{ng} / \mathrm{ml}\end{array}$ & $\begin{array}{l}\lambda_{\mathrm{ex}}=246 \mathrm{~nm} \\
\lambda_{\mathrm{em}}=376 \mathrm{~nm}\end{array}$ & - & - & $\begin{array}{l}\text { Pharmacokinetic } \\
\text { and } \\
\text { bioequivalence } \\
\text { studies }\end{array}$ & [33] \\
\hline 14. & $\begin{array}{l}\text { HILIC- } \\
\text { MS/MS }\end{array}$ & $\begin{array}{l}\text { Atlantis HILIC Silica } \\
\text { column }(5 \mu \mathrm{m}, 3 \mathrm{~mm} x \\
50 \mathrm{~mm}) .\end{array}$ & $\begin{array}{l}\text { ACN / Ammonium Format } \\
(100 \mathrm{mM}, \mathrm{pH} 4.5)(93: 7 \mathrm{v} / \mathrm{v})\end{array}$ & $\begin{array}{l}0,2-50 \\
\mathrm{ng} / \mathrm{mL}\end{array}$ & ESI MS/MS & - & $0,2 \mathrm{ng} / \mathrm{mL}$ & Blood plasma & [36] \\
\hline 15. & LC-MS/MS & $\begin{array}{l}\text { Agilent Zorbax Eclipse } \\
\text { XDB-C18 column }(1.8 \\
\mu \mathrm{m}, 50 \times 4.6 \mathrm{~mm}) \text { is } \\
\text { protected by security }\end{array}$ & $\begin{array}{l}5 \mathrm{mM} \text { ammonium formate with } \\
0.02 \% \text { formic acid and (B) } \\
0.02 \% \text { formic acid in } \\
\text { acetonitrile }(55: 45 \mathrm{v} / \mathrm{v}) \text { at a }\end{array}$ & $\begin{array}{l}1-500 \\
\mathrm{ng} / \mathrm{mL}\end{array}$ & MS & - & $1 \mathrm{ng} / \mathrm{mL}$ & Plasma serum & [38] \\
\hline
\end{tabular}




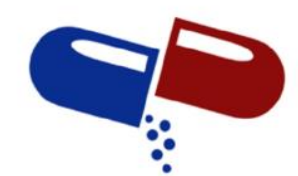

\section{IJPSM}

Devi Puspita et al, Int. Journal of Pharmaceutical Sciences and Medicine (IJPSM),

Vol.6 Issue. 2, February- 2021, pg. 1-11

ISSN: 2519-9889

Impact Factor: 3.426

\begin{tabular}{|c|c|c|c|c|c|c|c|c|c|}
\hline & & $\begin{array}{l}\text { guard cartridge C18 (4 x } \\
2 \mathrm{~mm})\end{array}$ & $\begin{array}{l}\text { flow rate of } 1.1 \mathrm{~mL} / \mathrm{min} . \\
\text { Thermostat mobile phase at } 40 \\
\pm 0.5^{\circ} \mathrm{C}\end{array}$ & & & & & & \\
\hline 16. & LC-MS-MS & $\begin{array}{l}\text { XTerra MS C18 column } \\
(150 \mathrm{~mm} \times 2.1 \mathrm{~mm}, 3.5 \\
\mu \mathrm{m} \text { particle size }) \text { is } \\
\text { equipped with Xterra } \\
\text { MS C18 column } \\
(\text { particle size } 20 \mathrm{~mm} \times \\
2.1 \mathrm{~mm} \text {, particle size } 3.5 \\
\mu \mathrm{m})\end{array}$ & $\begin{array}{l}\text { The gradient mobile phase } \\
\text { consisted of acetonitrile- } 2 \mathrm{mM} \\
\text { ammonium acetate }(10: 90 \mathrm{v} / \mathrm{v}) \\
\text { as mobile phase A and } \\
\text { acetonitrile- } 2 \mathrm{mM} \text { ammonium } \\
\text { acetate }(90: 10 \mathrm{v} / \mathrm{v}) \text { as mobile } \\
\text { phase } \mathrm{B}, \text { phase A at time } 0.1, \\
8,10, \text { and } 15 \text { minutes are } 90 \% \text {, } \\
90 \%, 30 \%, 90 \% \text {, and } 90 \%, \\
\text { respectively. The flow rate is } \\
400 \mu \mathrm{L} / \mathrm{min} \text {, and the injection } \\
\text { volume is } 100 \mu \mathrm{L} \text {. }\end{array}$ & $\begin{array}{l}1-20 \\
\mathrm{ng} / \mathrm{mL}\end{array}$ & MS & $0,4 \mathrm{ng} / \mathrm{mL}$ & $1,2 \mathrm{ng} / \mathrm{mL}$ & $\begin{array}{l}\text { Pharmacokinetic } \\
\text { profile in dogs }\end{array}$ & [39] \\
\hline 17. & $\begin{array}{l}\text { UPLC- } \\
\text { MS/MS }\end{array}$ & $\begin{array}{l}\text { The } 2.1 \times 50 \mathrm{~mm} \\
\text { column is packed with } \\
1.7 \mu \mathrm{m} \text { particles } \\
\text { (ACQUITY UPLC BEH } \\
\text { C18 column, Waters) is } \\
\text { designed to withstand } \\
15,000 \text { psi. }\end{array}$ & 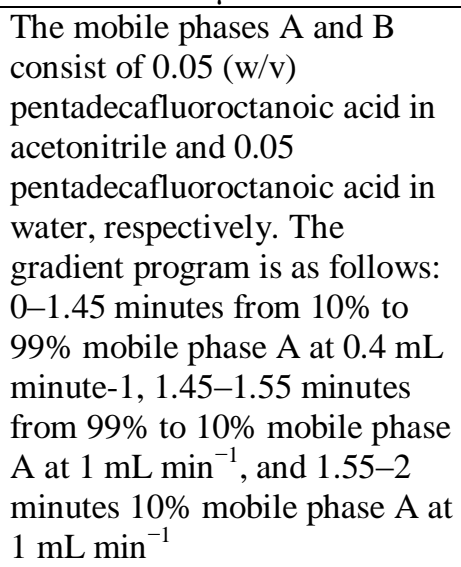 & $\begin{array}{l}0,2- \\
100 \\
\mathrm{ng} / \mathrm{mL}\end{array}$ & $\begin{array}{l}\text { Monitoring } \\
\text { reaction of } \\
\text { the } \\
\text { transition: } \mathrm{m} \\
\text { / z } 452 \rightarrow \\
344\end{array}$ & $\begin{array}{l}0,02 \\
\mathrm{ng} / \mathrm{mL}\end{array}$ & $0,07 \mathrm{ng} / \mathrm{mL}$ & Blood plasma & [41] \\
\hline
\end{tabular}

